\title{
Carica papaya seeds effectiveness as coagulant and solar disinfection in removal of turbidity and coliforms
}

\author{
Syeda Azeem Unnisa ${ }^{1}$ (D) Shaik Zainab $\mathrm{Bi}^{1}$
}

Received: 27 December 2017 / Accepted: 2 August 2018 / Published online: 3 September 2018

(c) The Author(s) 2018

\begin{abstract}
Carica papaya seeds of a tropical tree comprise water-soluble and positively charged protein known as cystine protease which emerged as a putative coagulant in both water and wastewater treatments. Natural coagulants applications have been posed in many evaluation assays through many years owing to the difficulties raised by usage of chemical coagulants. It is indispensable to optimize process variables such as $\mathrm{pH}$, turbidity, total dissolve solids (TDS), E. coli and coliforms counts accuracy to raise the efficiency of coagulation operation via employing $C$. papaya. Experimentally, employing jar tests supported by pretreatment, papaya seed protein as a natural coagulant, alum and solar disinfection to remove turbidity and bacteria was accomplished. The results revealed that the removal efficiency for turbidity was culminated up to $100 \%$ by incorporation of both alum and $C$. papaya seeds at lower dosages of coagulant about $0.2-0.6 \mathrm{mg} / \mathrm{L}$ at $30 \mathrm{~min}$. A significant difference was found for paired samples correlations around 0.130 by $p$ value $=0$, among TDS, $C$. papay $a$ and alum dosages and turbidity values. Employing a combined process resulted in turbidity and bacteria (most probable numbers of coliforms) removal around $100 \%$. The highest efficiency of solar disinfection system possessed to fell the sunlight exposure period time by up to $2 \mathrm{~h}$ with $100 \%$ removal of E.coli and coliforms.
\end{abstract}

Keywords Carica papaya seed $\cdot$ Coagulant $\cdot$ Disinfection $\cdot$ Microorganism $\cdot$ Turbidity

\section{Introduction}

Plant extracts which are natural have been exploited for water purification by many nations from ancient times. Majority of them are derived from the fruits of trees and plants, roots, bark or sap, seeds and leaves (Aho and Lagasi 2012). For instance, Nirmali tree (Strychnos Potatorum) seeds have been utilized as a clarifier from fourteenth and fifteenth centuries $\mathrm{BC}$ which were also declared to purify turbid river water around 4000 years ago in India (Alo et al. 2012; Amagloh and Benang 2009). It is further stated that in Peru, traditionally the water has been treated with the mucilaginous sap extracted of leaves of tuna released from certain species of cacti. In addition to cacti, Zea Mays was

Syeda Azeem Unnisa

syeda_30@yahoo.co.in

Shaik Zainab Bi

mail4zainab@gmail.com

1 Department of Environmental Science, University College of Science, Osmania University, Hyderabad, Telangana State 500007, India recognized as sedimentation agent by sailors in the sixteenth and seventeenth centuries. Coagulants which are natural release much lower sludge quantity; on the other hand, the natural alkalinity is retained during the process of treatment; they are biodegradable, safe to human and cost-effective since they are locally cultivated, and various effective dosage ranges can be used for flocculation and coagulation (AWWA 1995; Anwar and Rashid 2007). Strychnos potatorum seeds powder removes bacteria in the range of 90-99\% which has also been determined (Arafat and Mohamed, 2013).

The earlier studies on the coagulation and disinfection efficiency with Tuberregium sclerotium, Moringa oleifera, Hibiscus sabdariffa, Jatropha curcas, Pleurotus and Alum were evaluated on wastewater samples for removal of turbidity. Coagulation efficiency of approximately $90 \%$ was achieved for the $M$. oleifera with a significant rise in disinfection efficiency. Also, according to report, the flocculation-coagulation efficiency was superior in highly polluted waters when compared to less polluted water samples supported by a water softener in following the procedure (Shan et al. 2017; Bina et al. 2010).The main purpose of water treatment is to eliminate bacteria and impurities to 
meet and observe the drinking water quality guidelines (Bina et al. 2009). Moringa oleifera seeds are widely regarded for nontoxic, eco-friendly and simplified water treatment operations for people who are accommodated in extreme poverty (Briggs 2003). With regard to many assays published to some of the waterborne pathogens, $M$. Oleifera seeds have exhibited sufficient resistance (Broin et al. 2002; Divakaran and Pillai, 2002; Ebeling and Sibrell 2003; Egbuikwem and Sangodoyin 2013). Madsen et al. (1987) in Sudanese villages have investigated the effect of water coagulation by seeds of M. Oleifera on turbidity removal, bacterial concentrations and E.coli. Mangale et al. (2012a, b) utilized $M$. Oleifera seeds as natural absorbent to purify ground water using different doses of around 50, 100 and $150 \mathrm{mg} / \mathrm{l}$ in the presence of $\mathrm{pH}$, turbidity, TDS, TS, hardness, chlorides, alkalinity, acidity and coliforms. Tantra (2018) investigated the efficacy of Vagbhatokta Jala Nirvishikarana (VJN) in turbid water. Megersa et al. (2016) employed indigenous plant species for drinking water treatment in developing countries.

Safe and potable drinking water is urgent to keep the good health and welfare of a society. The water resources must withstand required levels of purification prior to consumption. Different practices are employed to access safe and purified water to the consumer pertaining to raw water resource characteristics. One of the serious difficulties posed with surface water treatment is the widespread seasonal variations in turbidity (Eman et al. 2014). High efficiency of suspended solid sedimentation can be acquired via chemical coagulants applications such as salts of aluminum and iron. This treatment process mechanism pursues the integration and aggregation of suspended particles to make up and settles the flocs by both destabilization and neutralization processes upon the charged colloids. Intensively, the process has recognized some interplays and propensities with temperature, $\mathrm{pH}$, effluent quality, dosage and kind of coagulant (Jabeen et al. 2008). The suspended particles can be differentiated obviously in variety of ways such as source, particle size, charge nature, shape, density and scheme. Reliable application of flocculation and coagulation operation and coagulation selection are pertained on discerning the interaction and interplay among various factors. In this regard, an effort has been made in this study to evaluate the efficiency and performance of $C$. papaya seeds and alum for removal of turbidity and solar disinfection for bacterial removal.

\section{Materials and methods}

\section{Microbiology analysis}

The sample preparation has accomplished by a dilution step $1 / 9$ of sterile distilled water and then serially diluted up to $10-5$ dilution and plated in triplicates on both of Mc Conkey and Eosin Methylene Blue (EMB) agars applied so that total coliform and E. coli counts were measured at $37{ }^{\circ} \mathrm{C}$ during $24 \mathrm{~h}$, respectively. Discrete colonies on each plate were thoroughly counted, and the average of 3 plates was assumed.

\section{Coagulant}

Natural coagulant $C$. papaya seeds were purchased from local market of Telangana State, Hyderabad. By grinding and sieving seeds, its powder was prepared with a pore size of $0.4 \mathrm{~mm}$. Figure 1 represents the seeds powder used for treatment process. Around 0.2, 0.4 and $0.6 \mathrm{mg} / \mathrm{l}$ of the smaller fractions were suspended in distilled water and stirred 10 min on a magnetic stirrer (Elico PE 138) to extract effective coagulant.

\section{Coagulation tests}

The coagulation activity was investigated by jar test using various Kaolin concentrations ranging from about 20 to 60 NTU according to Fig. 2. The jar tests were conducted by adding different values of extracts to about $1000 \mathrm{ml}$ of water followed by rapid (200-250 rpm) and slow mixing (30-40 rpm; by Thermo Fisher Scientific Max Q 2000) processes around 1-3 and 12-15 min and then system was left to sediment suspended solids for $1 \mathrm{~h}$, respectively. After sedimentation period for $1 \mathrm{~h}$, residual turbidity was measured in $50 \mathrm{ml}$ of upper clarified liquid using turbidity meter (Elico CL 52 D) by varying a few experimental variables which were $\mathrm{pH}$, coagulant dosages and mixing time (Pan et al. 1999; Jin 2005).

\section{Solar exposure}

Polyethylene terephthalate (PET) bottles of transparent, clear plastic, cylinder shape containing a surface area of $23 \times 7.2 \times 6.0 \mathrm{~cm}$ were utilized experimentally for around $2-8 \mathrm{~h}$ in utmost sunlight from 10 am to $2 \mathrm{pm}$. Six samples were decanted from jar test beakers and accommodated in

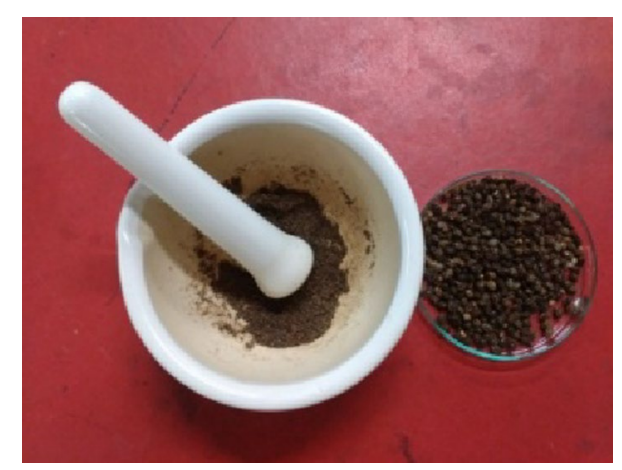

Fig. 1 Seeds powder used for treatment 


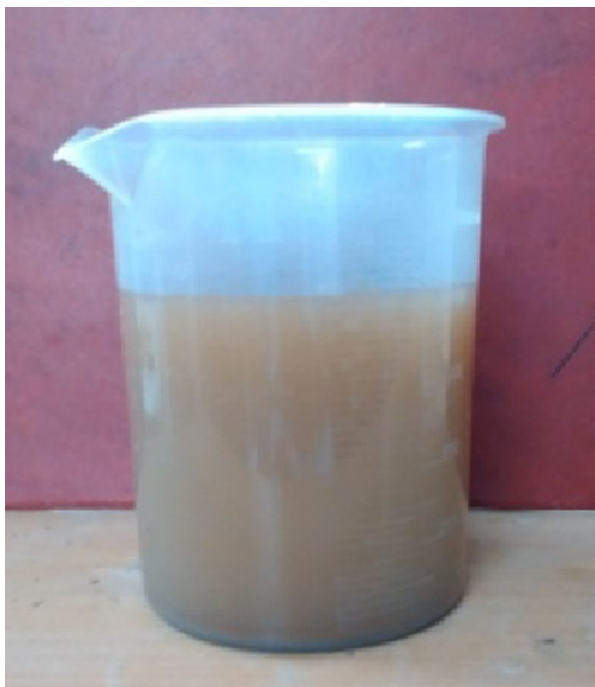

Fig. 2 Soil sample mixed with water

3 available PET bottles as test bottles (exposed to sunlight), control bottles (kept in dark room) and temperature measurement bottles in the sunlight. Both of test and temperature bottles were placed in the roof of the institute horizontally on a southward-facing corrugated metal sheet at approximately 10.00 am for solar treatment, while dark bottles were preserved within a closed cardboard box in the laboratory. Samples were picked up prior to coagulation operation and after zero to $6 \mathrm{~h}$ of sunlight exposure, followed by a 24-h re-growth period ( $18 \mathrm{~h}$ in the dark at room temperature) frequently. Around 24-h samples were taken from tests steps and control bottles transferred to investigate re-growth rate of E. coli. Samples for microbial analysis were embedded on differential coliform (DC) ambient agar (based on MOE Method \#E3407) to monitor the E. coli and coliform concentrations.

\section{Physiological study of water}

For water samples, physiochemical parameters were scrutinized prior and after treatment with seed solution of $C$. papaya using $\mathrm{pH}$ meter (A 215 thermometer), Nephlo Turbidimeter (NTU), digital TDS meter (PPM) and eosin methylene blue media $(\mathrm{Cfu} / \mathrm{ml})$ for $E$. coli monitoring.

\section{Results and discussion}

\section{Effect of coagulants extracts}

In order to treat turbid water natural coagulants and solar disinfection was used where the results are depicted in tables and figures. Figures 3 and 4 and Table 1 show the synthetic samples, flocculation-coagulation with seeds powder filtration, and the effect of alum and solar disinfection on various turbid waters, respectively. According to Table 1, the TDS amounts were detected in high ranges in treated water samples, which might be reasonable because of the dissolving the dissolved solids ions and salts (Kalogo et al. 2000). Turbidity can influence and alter the organoleptic properties of water and also protect pathogens in the distribution system that can be major causes of waterborne diseases (Kawo 2007).

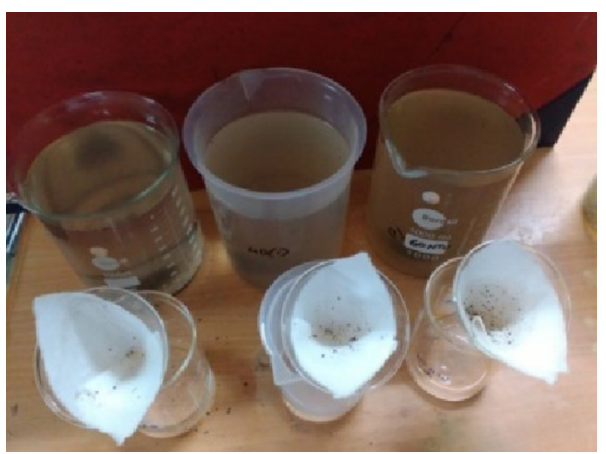

Fig. 4 Flocculation-coagulation with seeds powder filtration
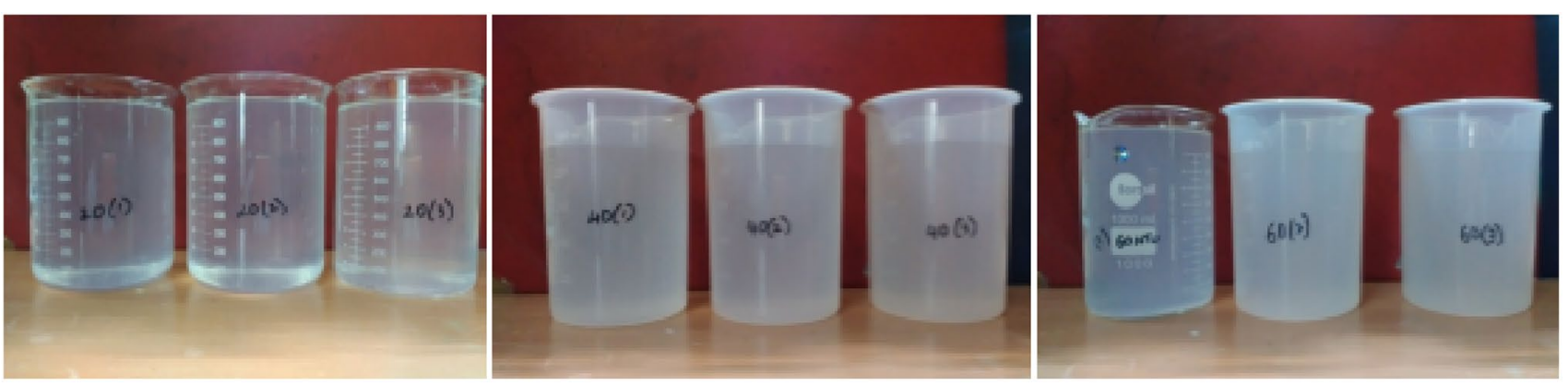

Fig. 3 Synthetic samples 
Table 1 Effect of alum and solar disinfection on various turbid waters

\begin{tabular}{|c|c|c|c|c|c|c|c|c|c|c|c|c|}
\hline \multirow[t]{3}{*}{ No } & \multirow{3}{*}{$\begin{array}{l}\text { Treatment } \\
\text { time (min) }\end{array}$} & \multirow{3}{*}{$\begin{array}{l}\text { Alum quan- } \\
\text { tity }(\mathrm{gm}) / \mathrm{l}\end{array}$} & \multirow{2}{*}{\multicolumn{2}{|c|}{$\mathrm{pH}$}} & \multirow{2}{*}{\multicolumn{2}{|c|}{$\begin{array}{l}\text { Turbidity } \\
\text { (NTU) }\end{array}$}} & \multirow{2}{*}{\multicolumn{2}{|c|}{ TDS (mg/l) }} & \multicolumn{4}{|c|}{ Solar disinfection } \\
\hline & & & & & & & & & \multicolumn{2}{|c|}{$\begin{array}{l}\text { E. } \operatorname{coli}(\mathrm{cfu} / \\
\mathrm{ml})\end{array}$} & \multicolumn{2}{|c|}{$\begin{array}{l}\text { Coliform } \\
\text { (cfu/ml) }\end{array}$} \\
\hline & & & BT & AT & BT & AT & BT & AT & BT & AT & BT & AT \\
\hline 1 & 30 & 0.2 & 5 & 6 & 20 & 0 & 45 & 74 & 340 & 0 & 543 & 0 \\
\hline 2 & 30 & 0.2 & 6 & 6 & 40 & 0 & 83 & 103 & 322 & 0 & 498 & 0 \\
\hline 3 & 30 & 0.2 & 6 & 6 & 60 & 0 & 139 & 164 & 354 & 0 & 478 & 0 \\
\hline 4 & 30 & 0.4 & 6 & 7 & 20 & 0 & 45 & 70 & 316 & 0 & 524 & 0 \\
\hline 5 & 30 & 0.4 & 6 & 7 & 40 & 0 & 83 & 107 & 342 & 0 & 518 & 0 \\
\hline 6 & 30 & 0.4 & 6 & 7 & 60 & 0 & 139 & 185 & 327 & 0 & 506 & 0 \\
\hline 7 & 30 & 0.6 & 6 & 6 & 20 & 0 & 45 & 100 & 313 & 0 & 511 & 0 \\
\hline 8 & 30 & 0.6 & 6 & 6 & 40 & 0 & 83 & 152 & 321 & 0 & 532 & 0 \\
\hline 9 & 30 & 0.6 & 6 & 6 & 60 & 0 & 139 & 185 & 312 & 0 & 515 & 0 \\
\hline
\end{tabular}

$B T$ before treatment; $A T$ after treatment
The coagulation-flocculation method is regarded the best outstanding surface water treatment process. Coagulation-flocculation process help the impurities to coagulate and form the floc which is settled at the bottom. Flocculation paves, by the slow mixing of the synthetic or natural polymers, to enhance the aggregation process and combine together the micro-flocs for destabilization of particles and agglomerating them into larger flocs which can be separated subsequently by either precipitation or filtration processes. Nowadays, the application of environmentally friendly natural coagulants is getting more publicity which is mentioned as ubiquitous alternative for water treatment targets. Organic polymers which are natural are called as biopolymers which are generated or released from many resources such as microorganisms, animals and plant tissues which are safe for human and biodegradable in nature. Their exploitation as coagulants is getting some advantageous because they are efficient in low dosage, produces less sludge quantity and have negligible impact on $\mathrm{pH}$ and alkalinity (Shirasaki et al. 2017).

\section{Optimization of $\mathrm{pH}$}

It was perceived that treating turbid water with $C$. papaya seed powder, the $\mathrm{pH}$ of the sample was descended from 7.8 to 7.2 and 7.6 to 7.5 by addition of 0.2 and $0.6 \mathrm{mg} / \mathrm{l}$ of seed powder, respectively. The $\mathrm{pH}$ will not only have impact on the surface charge of coagulants, but also impresses the suspension stability. In addition, coagulant protein solubility in aqueous solution was impressed by variations in $\mathrm{pH}$. Thus, the $\mathrm{pH}$ study was indispensable to distinguish the $\mathrm{pH}$ optimum value of the treatment system. The alum efficiency utilized as a coagulant is intensively influenced by $\mathrm{pH}$ variations. At optimum situations, the flocs are rigid and immense, which settles impressively in less than $20 \mathrm{~min}$. Madsen et al. (1987) in Sudanese villages have investigated the effect of water coagulation by seeds of M. Oleifera on turbidity removal, bacterial concentrations and E.coli. The $M$. Oleifera seed material was used as a coagulant to treat the turbid waters at $30{ }^{\circ} \mathrm{C}$, which was found to reduce turbidity around $80-99.5 \%, 1-4-\log$ bacteria reduction (90-99.99\%) by an optimized pH. Mangale et al. (2012a, b) utilized $M$. Oleifera seeds as natural absorbent to purify ground water using different doses of around 50,100 and $150 \mathrm{mg} / \mathrm{l}$ in the presence of $\mathrm{pH}$, turbidity, TDS, TS, hardness, chlorides, alkalinity, acidity, coliforms. Mangale et al. (2012a, b) utilized $M$. Oleifera seeds as natural absorbent to purify ground water using different doses of around 50, 100 and $150 \mathrm{mg} / \mathrm{l}$ in the presence of $\mathrm{pH}$, turbidity, TDS, TS, hardness, chlorides, alkalinity, acidity, coliforms. The optimum $\mathrm{pH}$ was 7 and was similar to the obtained results of the current study.

The utmost removal of various ranges of turbidity with alum was obtained at $\mathrm{pH}$ of 7 . Alum coagulation efficiency at $\mathrm{pH} 6$ has appeared almost to that of $\mathrm{pH} 7$. Also, the highest turbidity elimination was achieved at $\mathrm{pH}$ of 7 . The coherence between the optimum dosage, $\mathrm{pH}$ and turbidity descended values proved that the optimum dosage of protein coagulant in acidic phase was lower. This phase can be associated in the rise of protonated amine groups number which are connected to protein coagulant at lower $\mathrm{pH}$ where similar findings were revealed when chitosan was applied as a coagulant by Mangale et al. (2012a, b). The initial turbidity of samples was high at amounts in comparison with World Health Organization allowable values. It was found that after applying the treatment process the turbidity presented a fell from 60 to $0 \mathrm{NTU}$ using 0.4 to $0.6 \mathrm{mg} / \mathrm{l}$ alum, respectively. Due to this treatment process, there was agglomeration in the floc size and its settlement. This analysis proved that with a rise in the dose of coagulant the turbidity reached a pitfall to an allowable level according to Table 2 .

Turbidity elimination was emerged at both lower $\mathrm{pH}$ values and smaller floc diameters. This was accompanied by a 
slower sedimentation velocity which can be explained by the variations in the configuration of cysteine protein coagulant. The neutral solutions can coiled the structures and allow the coagulant protein to form and release larger and denser flocs. In acidic ambient, it converts to a more developed and sustained chain that generates looser and smaller flocs and additionally the effect of $\mathrm{pH}$ on the protein coagulation efficiency is insensible (Connachie et al. 1999).

\section{Mixing time optimization}

The rapid mixing was employed in coagulation process, to scatter out the coagulant throughout the turbid water, whereas in flocculation process, slow mixing was a prominent factor to achieve the most favorable for floc formation performance. Sufficient time was assigned to pave joining the particles to make up well-matured size of floc and consequently their efficient role in precipitation process (Meneghel et al. 2013). One of the operating factors is flocculation time that confers profoundly considered in water treatment plant. The pitfall in turbidity was perceived to be prodigious at intensive rotations per minute (rpm), especially around $100-30 \mathrm{rpm}$ at various $\mathrm{pH}$ intervals. The turbidity results were overlap with the studies accomplished by Muyibi and Evison (1995). They used M. Oleifera seed suspension for the softening of hard water via jar tests. Ndibewu et al. (Ndibewu et al. 2011) asserted that residual turbidity substantial reduction was perceived by S.S-g-PA. The efficiency performance of S.S-g-PA was figured to be an appropriate coagulant with considering advantages of the biodegradability of S.S-g-PAml as well as less dosage of S.S-g-PA applied as compared to slurry alum.

\section{Coagulant dose effect}

Dose of coagulant is one of the most prominent factors which have been regarded for manifestation of appropriate amounts of the coagulant performance in both stages of coagulation and flocculation. High dosage or overdosing can lead to inefficient performance of flocculation process. Hence, it is important to figure out the appropriate dose to minimize and adjust both dosing outlays and release of sludge to reach the optimum performance in treatment (Nnaji 2012). The optimum alum dosage was possessed to be about $0.2 \mathrm{mg} \mathrm{L}^{-1}$ which was the lowest dosage expected, so it resulted in the utmost turbidity elimination. In the present study, the best performance of alum in eliminating water turbidity was manifested at $\mathrm{pH} 7$ followed by $\mathrm{pH}$ of 6 according to Table 2 . The coagulation efficiency of alum was fixed almost constant within the dosage range of $0.4-0.6 \mathrm{mg} \mathrm{L}^{-1}$. Further, overdosing was prosecuted for medium to low turbidity waters. The removal efficiency of turbidity was slightly declined by increasing alum dosage from 0.2 to $0.6 \mathrm{mg} \mathrm{L}^{-1}$, and it reduced from 97.1 to $95.7 \%$ at $\mathrm{pH}$ of 6 . It is worth to mention that initial turbidity was around 100 NTU and the reason for declining can be associated with destabilization of colloidal particles due to overdosing and charge reversal.

Tantra (2013) investigated the efficacy of Vagbhatokta Jala Nirvishikarana (VJN) in turbid water. VJN considerably reduced E.coli and most probable number of coliforms at the concentration of 3 drops in $100 \mathrm{ml}$ of water samples at 30 min. Nandini and Sheba (2016) studied the trends in the usage of bio-coagulants in turbidity removal efficiency with natural coagulants available as a review survey. It was found that natural coagulants including Nephelium lappaceum, J. curcas, Plantagoovato, Guar gum, Rambutan (N. lappaceum), Chitosan generated only $20-30 \%$ of alum treated counterpart. The study by Megersa et al. (2014) reported that taking initial turbidities of 20, 45, 46, 80 and 195 NTU with the flocculent dosages of 10, 20, 30, 40, 50, 60, 70, 80,90 and $100 \mathrm{mg} / \mathrm{l}$, tubers of Maerua subcordata offered an elimination efficiency up to $98 \%$ of turbidity using optimum dosages of around 20 to $80 \mathrm{mg} / \mathrm{l}$ in $6 \mathrm{~h}$ of precipitation period, and about $99.9 \%$ of microbial removal was achieved
Table 2 Effect of $C$. papaya seed powder and solar disinfection on various turbid waters

\begin{tabular}{|c|c|c|c|c|c|c|c|c|c|c|c|c|}
\hline \multirow[t]{3}{*}{ No. } & \multirow{3}{*}{$\begin{array}{l}\text { Treatment } \\
\text { time (min) }\end{array}$} & \multirow{3}{*}{$\begin{array}{l}\text { C. papaya seed } \\
\text { quantity }(\mathrm{gm}) / 1\end{array}$} & \multirow{2}{*}{\multicolumn{2}{|c|}{$\mathrm{pH}$}} & \multirow{2}{*}{\multicolumn{2}{|c|}{$\begin{array}{l}\text { Turbidity } \\
\text { (NTU) }\end{array}$}} & \multirow{2}{*}{\multicolumn{2}{|c|}{ TDS (mg/l) }} & \multicolumn{4}{|c|}{ Solar disinfection } \\
\hline & & & & & & & & & \multicolumn{2}{|c|}{$\begin{array}{l}\text { E. coli }(\mathrm{cfu} / \\
\mathrm{ml})\end{array}$} & \multicolumn{2}{|c|}{$\begin{array}{l}\text { Coliform } \\
(\mathrm{cfu} / \mathrm{ml})\end{array}$} \\
\hline & & & BT & AT & BT & AT & BT & AT & BT & AT & BT & AT \\
\hline 1 & 30 & 0.2 & 5 & 7 & 20 & 0 & 80 & 74 & 340 & 0 & 543 & 0 \\
\hline 2 & 30 & 0.2 & 6 & 7 & 40 & 0 & 100 & 103 & 322 & 0 & 498 & 0 \\
\hline 3 & 30 & 0.2 & 6 & 7 & 60 & 0 & 140 & 164 & 354 & 0 & 478 & 0 \\
\hline 4 & 30 & 0.4 & 6 & 7 & 20 & 0 & 80 & 70 & 316 & 0 & 524 & 0 \\
\hline 5 & 30 & 0.4 & 6 & 7 & 40 & 0 & 115 & 107 & 342 & 0 & 518 & 0 \\
\hline 6 & 30 & 0.4 & 6 & 7 & 60 & 0 & 110 & 185 & 327 & 0 & 506 & 0 \\
\hline 7 & 30 & 0.6 & 6 & 7 & 20 & 0 & 120 & 100 & 313 & 0 & 511 & 0 \\
\hline 8 & 30 & 0.6 & 6 & 7 & 40 & 0 & 140 & 152 & 321 & 0 & 532 & 0 \\
\hline 9 & 30 & 0.6 & 6 & 7 & 60 & 0 & 180 & 185 & 312 & 0 & 515 & 0 \\
\hline
\end{tabular}


which was analogous to chlorine disinfection efficiency with full conformance with World Health Organization standards, taking into account its application in low-income countries which made it an excellent candidate for water treatment operation in Ethiopia. Megersa et al. (2016) figured out that seeds from $M$. Oleifera got enough eligibility as a kind of plant in order to complete water treatment targets, particularly in rural areas.

\section{Solar disinfection experiments}

Natural sunlight has been confirmed to confer germicidal properties. It was revealed that natural light exposure of approximately $2000 \mathrm{~kJ} / \mathrm{m}^{2}$ or $555 \mathrm{Wh} / \mathrm{m}^{2}$ led to 3-log inactivation of $E$. coli. Viruses withstand this process more resistant than bacteria for the same inactivation exposures. Experimentally, the solar irradiance was implemented and conducted for 3-day utilization so that the disinfection operation. Solar light is an indicative of the amounts of both available $U_{\mathbf{3 1 5 - 4 1 5}}$ and visible irradiation for disinfection operation, so it is one of the major factors influencing solar treatment efficiency (Amara et al. 2017). Figure 5 displays the solar disinfection employed by the current research.

The natural $E$. coli made up approximately $0.05-5 \%$ of the natural total coliforms (TCs) probable numbers or concentrations. The presence of colonies on Mc Conkey agar confirmed probable presence of typical coliforms with the absence of spores. Colonies on EMB appeared as metallic greenish sheen proved the presence of $E$. coli. up to $2 \mathrm{~h}$ of sunlight exposure was demanded for the natural $E$. coli

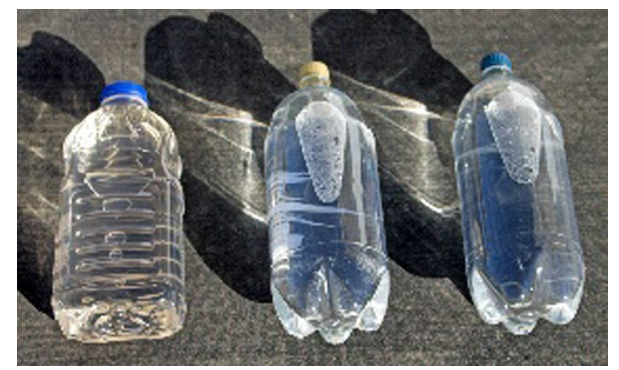

Fig. 5 Solar disinfection elimination, while it was obtained up to 3 to $6 \mathrm{~h}$ for natural TCs. Cultured and natural $E$. coli concentrations reached below the allowable detection limit after 2 to $4 \mathrm{~h}$ of sunlight exposure. No E. coli species emerged after $18 \mathrm{~h}$ storage period for each experiment. Table 3 and Fig. 6 present the combined turbid water treatment samples.

The results generally proved strongly that natural materials applied had strong ability to purify turbid water. Despite the materials alone cope with treating water and wastewater, incorporation of the material with solar disinfection has a further advantage in treating turbid water as demonstrated according to Table 3. Dawney et al. (2014) utilized table of $\mathrm{NaCl}$ to remove turbidity in water as a pretreatment step for colloidal clay particles supported by Jar tests resulted to about $92 \%$ particle removal efficiency in South Sudan. It has also been suggested that complementary process use very low amounts of bentonite to raise the turbidity removal and solar system for microorganism elimination targets. Giannakisa et al. (2016) reported that using solar system procured the highest disinfection efficiencies for both of water and wastewater treatments applications. The microbial load in the water can be reduced by solar disinfection practice, making it potable. The results proved that water samples from various rural water resources met the drinking water standards with a significant decline in microbial loads by (Devi and Lalitha 2016). Also, the study done by FernandezIbanez et al. (2017) is in full agreement and conformance with results and findings of present study.

\section{Conclusion}

Promotion and development of $C$. papaya seeds as a natural coagulant offered many diverse advantages to many countries of the developing world. Therefore, it created us a sustainable, useful, effective and robust water treatment product. Turbidity was removed up to $100 \%$ after treatment with no significant change on the $\mathrm{pH}$ values. As the natural coagulant remediated turbidity of the water additionally sunlight as a renewable energy demanded for disinfection, so it is recommended. It was found that seeds as natural coagulants procured high reduction percentages of turbidity
Table 3 Water analysis parameters for combined turbid water treatment samples

\begin{tabular}{lccccc}
\hline Parameter & Alum treatment & & \multicolumn{2}{c}{ C. papaya seed treatment } \\
\cline { 2 - 3 } \cline { 5 - 6 } & $\mathrm{BT}$ & $\mathrm{AT}$ & & $\mathrm{BT}$ & $\mathrm{AT}$ \\
\hline $\mathrm{pH}$ & $5.88 \pm 0.33$ & $6.33 \pm 0.5$ & & $5.88 \pm 0.33$ & $7.0 \pm 00$ \\
Turbidity & $40 \pm 17.32$ & $0 \pm 0$ & & $40 \pm 17.32$ & $0 \pm 0$ \\
TDS & $126.66 \pm 45.39$ & $89 \pm 40.95$ & & $126.66 \pm 45.39$ & $118.33 \pm 31.81$ \\
E. coli & $327.44 \pm 14.68$ & $0 \pm 0$ & & $327.44 \pm 14.68$ & $0 \pm 0$ \\
Coliforms & $504.11 \pm 19.21$ & $0 \pm 0$ & & $513.88 \pm 19.06$ & $0 \pm 0$ \\
\hline
\end{tabular}

$B T$ before treatment, $A T$ after treatment 


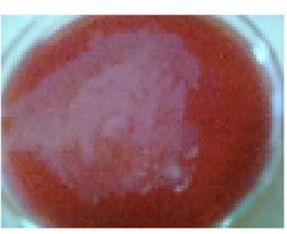

E. coli count
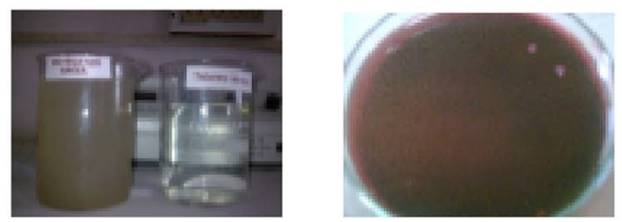

Treatment with

E. coli count natural coagulant (NC) after NC treatment

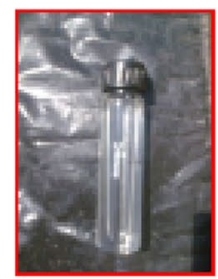

Solar

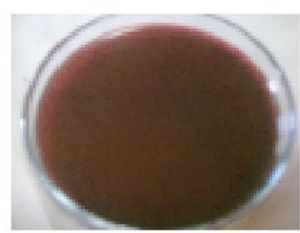

E. coli count after

In turbid water disinfection

Fig. 6 Combined turbid water treatment samples

and other impurities in comparison with alum. Employing seeds powder to purify turbid water created some positive attentions such as being eco-friendly and cheap products to use. The seeds as natural coagulant supported by solar disinfection composed a combined or integrated practice which can be utilized in rural areas to turbid water treatment operations.

Acknowledgements The authors are grateful to the University Grants Commission (UGC) F. No-43-335/2014 (SR) dated: 6th September, 2015, New Delhi, for providing the Grant under UGC-Major Research Project.

\section{Compliance with ethical standards}

Conflict of interest The work described has not been published before; it is not under consideration for publication anywhere else; its publication has been approved by all co-authors, if any, as well as by the responsible authorities - tacitly or explicitly-at the institute where the work has been carried out. The publisher will not be held legally responsible should there be any claims for compensation.

Open Access This article is distributed under the terms of the Creative Commons Attribution 4.0 International License (http://creativeco mmons.org/licenses/by/4.0/), which permits unrestricted use, distribution, and reproduction in any medium, provided you give appropriate credit to the original author(s) and the source, provide a link to the Creative Commons license, and indicate if changes were made.

\section{References}

Aho IM, Lagasi JE (2012) A new water treatment system using Moringa oleifera seed. Am J Sci Ind Res 3(6):487-492

Alo MN, Anyim C, Elom M (2012) Coagulation and antimicrobial activities of Moringa oleifera seed storage at $3 \mathrm{LC}$ temperature in turbid water. Adv Appl Sci Res 3:887-894

Amagloh FK, Benang A (2009) Effectiveness of Moringa oleifera seed as coagulant for water purification. Afr J Agric Res 4(2):119-123

Amara S, Baghdadli T, Nordell B, Khimulu R (2017) Solar system design for water treatment: antibacterial heat exchanger (ABHE). In: Qudrat-Ullah H, Tsasis P (eds) Innovative healthcare systems for the 21st century. Understanding complex systems. Springer, Cham, pp 34-36
American Water Works Association (AWWA) (1995) Standard methods for the examination of water and wastewater. American Public Health Association Inc., New York

Anwar F, Rashid U (2007) Physico-chemical characteristics of Moringa oleifera seeds and seed oil from a wild provenance of Pakistan. Pak J Biol Sci 39(5):1443-1453

Arafat MG, Mohamed SO (2013) Preliminary study on efficacy of leaves, seeds and bark extracts of Moringa oleifera in reducing bacterial load in water. Int J Adv Res 1:124-130

Bina B, Mehdinejad MH, Nikaeen M, Movahedian Attar H (2009) Effectiveness of chitosan as natural coagulant aid in treating turbid waters. Iran J Environ Health Sci Eng 6(4):247-252

Bina B, Mehdinejad MH, Gunnel D, Rajarao G, Nilaeen M, Movahedian A (2010) Effectiveness of Moringa oleifera coagulant protein as natural coagulant aid in removal of turbidity and bacteria from turbid waters. World Acad Sci Eng Technol 4(7):7-28

Briggs D (2003) Environmental pollution and the global burden of disease. Br Med Bull 2003:1-24

Broin M, Santaella C, Cuine S, Kokou K, Peltier G, Joet T (2002) Flocculent activity of a recombinant protein from Moringa oleifera Lam. Seeds. Appl Microbiol Biotechnol 60(1-2):114-119

Connachie GL, Folkard GK, Mtawali MA, Sutherland JP (1999) Field trials of appropriate hydraulic flocculation processes. Wat Res 33(6):1425-1434

Dawney B, Cheng C, Winkler R, Pearce JM (2014) Evaluating the geographic viability of the solar water disinfection (SODIS) method by decreasing turbidity with $\mathrm{NaCl}$ : a case study of South Sudan. Appl Clay Sci 99:194-200

Devi AV, Lalitha CH (2016) Treatment of drinking water in rural areas by solar disinfection method. World J Pharm Pharm Sci 5(3):1606-1620

Divakaran R, Pillai VN (2002) Flocculation of river silt using chitosan. Water Res 36(9):2414-2418

Ebeling JM, Sibrell PL (2003) Ogden SR, Summer felt ST. Evaluation of chemical coagulation/flocculation aids for the removal of suspended solids and phosphorus from intensive recirculating aquaculture effluent discharge. Aquacult Eng 29(1-2):23-42

Egbuikwem PN, Sangodoyin AY (2013) Coagulation efficacy of Moringa oleifera Seed extract compared to alum for removal of turbidity and $E$. coli in three different water sources. EurInt. J Sci Technol 2(7):13-20

Eman NA, Tan CS, Makky EA (2014) Impact of Moringa oleifera cake residue application on waste water treatment: a case study. J Water Resour Prot 6:677-687

Fernandez-Ibanez P, Guigan MC, Fatta-Kassino D (2017) Really help in the fight against water shortages. Europhys News 48(3):26-30

Giannakisa S, Lopezb MP, Spuhlera D, Perezc JS, Ibanezb FP, Pulgarina C (2016) Solar disinfection is an augmentable,

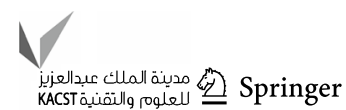


in situ-generated photo-Fenton reaction-Part 2: a review of the applications for drinking water and wastewater disinfection. Appl Catal B 198:431-446

Jabeen R, Shahid M, Jamil A, Ashraf M (2008) Microscopic evaluation of the antimicrobial activity of seed extracts of Moringa oleifera. Pak J Bot 40(4):1349-1358

Jin Y (2005) Use of high resolution photographic technique for studying coagulation/flocculation in water treatment. M.Sc Thesis, University of Saskatchewan, Saskatoon

Kalogo Y, Rosillon F, Hammer F, Verstraete W (2000) Effect of a water extract of Moringa oleifera seeds on the hydrolytic microbial species diversity of a UASB reactor treating domestic wastewater. Lett Appl Microbiol 31:259-264

Kawo AH (2007) Water purification potentials and in vivo toxicity evaluation of the aqueous and petroleum ether extracts of Calotropis procera, Latex and Moringa oleifera Lam seed powder. $\mathrm{PhD}$ thesis. Microbiology Unit, Department of Biological Sciences, Bayero University, Kano

Madsen M, Schlund J, Omer EF (1987) Effect of water coagulation by seeds of Moringa oleifera on bacterial concentrations. J Tropol Med Hyg 90:101-109

Mangale SM, Chonde SG, Raut PD (2012a) Use of Moringa oleifera (drumstick) seed as natural absorbent and an antimicrobial agent for ground water treatment. Res J Recent Sci 1:31-40

Mangale SM, Chonde SG, Jadhav AS, Raut PD (2012b) Study of Moringa oleifera (Drumstick) seed as natural absorbent and antimicrobial agent for river water treatment. J Nat Prod Plant Resource 2(1):89-100

Megersa M, Beyene A, Ambelu A, Woldeab B (2014) The use of indigenous plant species for drinking water treatment in developing countries: a review. J Bio Env Sci 5(3):269-281

Megersa M, Beyene A, Ambelu A, Asnake D, Bekele T, Firdissa B, Alebachew Z, Triest L (2016) A preliminary evaluation of locally used plant coagulants for household water treatment. Water Conserv Sci Eng 1(2):95-102
Meneghel AP, Goncalves AC, Fernanda R (2013) Biosorption of cadmium from water using Moringa (Moringa oleifera Lam.) seeds. Water Air Soil Pollut 224:1383

Muyibi SA, Evison LM (1995) Moringa oleifera seeds for softening hard Water. Water Res 29(4):1099-1105

Nandini GK, Sheba MS (2016) Emanating trends in the usage of biocoagulants in potable water treatment: a review. Int Res J Eng Technol (IRJET) 3(11):970-974

Ndibewu PP, Mnisi RL, Mokgalaka SN (2011) Heavy metal removal in aqueous system using Moringa oleifera: a review. J Mater Sci Eng B1:843-853

Nnaji PC (2012) An investigation of the performance of various coagulants/flocculants in removing the turbidity of coal washery effluents. M. Eng. Thesis, Federal University of Technology, Owerri

Pan JR, Huang C, Chen S, Chung YC (1999) Evaluation of a modified chitosan biopolymer for coagulation of colloidal particles. Coll Surf Physicochem Eng Asp 147(3):359-364

Shan TC, Al Matar, Makky EA, Ali EN (2017) Assessment of drinking water bark extracts of Moringa oleifera in reducing bacterial load in water. Appl Water Sci 7(3):1369-1376

Shirasaki NN, Shirasaki T, Matsushita Y, Matsuik Murai K, Aochi A (2017) Elimination of representative contaminant candidate list viruses, coxsackie virus, echovirus, hepatitis A virus, and noro virus, from water by coagulation processes. J Hazard Mater 326(15):110-119

Tantra A (2013) An experimental study on the efficacy of Vagbhatokta Jala Nirvishikarana Yoga on polluted water. A Dissertation. K.L.E University Belgaum Karnataka, India

Taruna (2018) 2nd International Online Conference on Biological Sciences, Conference Proceedings.Rayder, pp 117-133

Publisher's Note Springer Nature remains neutral with regard to jurisdictional claims in published maps and institutional affiliations. 